\title{
Photography as a Source for Comparative Research of History and Culture of Local Old Believer Groups in the First Third of the 20th Century (through the example of the Old Believers of Bessarabia, Buryatia and Tuva)
}

\author{
Aleksander V. Kostrova* \\ and Aleksander A. Prigarin \\ a Irkutsk State University \\ 1 K. Marksa Str., Irkutsk, 664003, Russia \\ ${ }^{b}$ Odessa I. I. Mechnikov National University \\ 2 Dvorianskaia Str., Odessa, 65000, Ukraine
}

Received 12.01.2016, received in revised form 28.04.2016, accepted 29.10.2016

Photo materials are one of the important sources for the research of the history and culture of local Old Believer groups in the first third of the 20th century. Photography, genre pictures, the appearance of people printed in photos and this culture representatives' objective world-all these things give a lot of valuable materials for the study of regional Old Believers at the time. Analysis of changes in quantity, quality and the content of the photographs of that time allows us to estimate the character and pace of the Old Believer culture evolution. The photo documentary legacy, which reflected the particular qualities of the Old Believer culture of different regions, within the framework of comparative approach, also allows us to reveal and to make a comprehensive analysis of the specific features of the local Old Believer communities.

The article gradually explores the theory and practice of using source study photos, reveals the general and miscellaneous in different historical conditions of the Old Believer communities development in Bessarabia, Buryatia and Tuva. The comparative research of photo sets, which reflected their lives in the period under study has been undertaken. We have come to conclusion that the photo materials allow us to expand and to clarify other types of data sources significantly, and also enable to reveal the character and evolution peculiarity of the Old Believer traditional culture of different regions in its folk and church sense.

Keywords: Old Belief, Old Believers, the Semeyskie, the Lipovans, photography, historical source, Bessarabia, Buryatia, Tuva.

This article was prepared with the support of Russian Humanitarian Science Foundation grant №1614-17601.

DOI: $10.17516 / 1997-1370-2016-9-12-2947-2963$.

Research area: national history.

(C) Siberian Federal University. All rights reserved

* Corresponding author E-mail address: a_kostrov@mail.ru 


\section{Introduction}

Modern scientific practice provides multifold opportunities for culturological analysis of the phenomenon of photography and its role in human life. This trend is developing fruitfully within the framework of art history and theory of culture. However, ethnography and anthropology still often remain aloof from this set of issues. While the development of certain aspects of the photo creation and functioning apparently shows the development needs of the old and new epistemological methods of science in this direction.

In anthropology and related sciences there have already been successful examples of consideration of photography as an element of human culture reflecting the multi-layered reality (Alexandrov, 2005; Barthes, 1997; Lishaev, 2007; Males, 2007; Nurkova, 2006; Petrovskaya, 2002; Tolmacheva, 2009 et al.) Scientific experience reveals the effectiveness of using photographic materials as a source having polysemantic possibilities for historical practices of reconstruction of man and various man groups, their life activity and mentality.

We can learn a lot about the ethnic pictures of the world if we turn to the invariant and diversity of photographic standards, composite structures and evolution of genres. Their contents are not only technical capabilities of the era. An important significance has developed in culture conceptions and stereotypes about what, when and how to shoot and also how to use these photographic pictures.

\section{Theoretical framework}

Heuristic potential of a photo can be determined in two dimensions: what, when and how it is shot, as well as the reflection of contexts at the time of shooting and in comments. Photography is a document that was "created in the social reality and tells about it, that is why it requires a double reading: firstly, [the reading] of text-forming systems of meanings in signs and symbols, secondly, the importance of photographic situations." And since "cultural reality of the image acts as the subject of a text formation, the value of a picture creating situation is determined by the photographer and social interaction of the photographic process" (Males, 2007: 168-182). In our opinion, it does not make less sense in the future, as the fate of the photograph is another socio-cultural setting which is to look for content and meaning.

We can trace accentualization of the past experiences at all three levels of implementation of a photographic image. At the same time, photographic reality is a conglomerate of different planes of reality (who photographed, what was photographed, what was not photographed, what was the photograph taken for, what significance was attached by a photograph keeper, what comments were given on to a photography collector). Describing multilevel identity reflected, R. Barthes emphasized that "in front of the camera I am, at the same time, a person who I find myself, who I would like to be, who I would like to be found, a person seen by my photographer and someone who is used by him to show his art" (Barthes, 1997: 26). In this case the researcher is interested not only in the information that the photographer wanted to give, but also in the information got into the shot in addition to his accentualization, in other words, what he did not plan to shoot but did. Also, the photography ban is of interest in different cultures, as well as the nature of its evolution. This polysemantics has significant potential for the variety of epistemological and gnoseological trends.

We are convinced that we can talk about the relative independence of this type of source. The photographs become a kind of information carriers reflecting the chronological and ethnocultural realities as well as their owners. There is 
no doubt that they tell many things with as much "information pathos" as human memory translates that. However, photographic material cannot convey all the major cultural realities accurately from appearance to social institutions and from rituals to economic activities. Understandably, photographs cannot represent themselves as a valid source (many of the points are outside the boundaries of attention without survey data and other sources). But other ethnographic sources usually do not produce entirely self-contained data either.

\section{Methods}

Photo belongs to the so-called "mass sources", in which phenomenology is regarded in terms of "typicalness" or "chance." Based on the experience of the source study techniques in relation to this type of data, it is does not worth focusing so much on finding its unique features, but trying to legitimize a particular innovation with the help of quantitative accumulation of its visual manifestations. Especially because under the conditions of modern technologies development, collective efforts for the identification, preservation and formulary certificates processing are becoming more affordable. Research work with them requires solving theoretical questions which will be specified in the immediate practice.

Photography as a historical source is characterized by image visualization or illustrativeness (technical implementation of the expression "better to see once than hear a hundred times"). It is also characterized by a high level of reliability of the information captured. Furthermore, the picture often has a high degree of informativeness as it simultaneously contains several diverse information blocks. Most often, the focus of the photographer is a person (in his time and in his living environment). That is, at least we can see and analyze external (and, through them internal) qualities of the person, his age and gender, ethnic, social, professional, religious, cultural, or even political affiliation. A human pose, his posture, clothing and related items (or their lack) can give a lot of information about their lifestyle, work and outlook. The informativity increases considerably in the collective picture when relatives, friends, colleagues and others are imprinted together showing, thus, a special relationship with each other. The objective world of culture representatives, surrounding the photographed people, plays not the least role in the analysis of photographic material. It allows understanding the nature of the economy development and the way of life, material and spiritual culture of the people and society better. And this is invaluable information for historians, ethnographers and anthropologists.

It is also important to solve the authorship problem that arises when working with photographic material, as it is often in the person of the photographer that are the secrets of a selected scene, image quality, and, if anything, the original edition of the information chosen.

As for the direct analysis of a photograph content, it is obvious that each genre of the latter needs its own approach to develop. For example, in the analyzed period, a posed portraiture (often a group one) was the most widely spread, rather than, say, the pictorial photography that seem to be more informative. However, the correct approach turns this minus into a plus. Although the posed portraiture (except forensic photography) (Buraeva, 2005) often gives an image of how people would like to be imprinted (wealthy, festive, serious or funny, literate, "positive", etc.), in some way it provides information about behavior stereotypes, priorities system and the authorities existing in the society of his time. This is the first approximation. Making a deeper professional analysis of the surviving photographic material and their correlation with 
the other types and kinds of historical sources (Karpenko, 2013: 275), it is possible reveal a lot of valuable information on various aspects of the history and culture.

\section{Statement of the problem}

From the variety of theoretical and methodological principles of attitudes to photography in the modern science, we are interested in two fundamental questions in this research situation.

1. The role of photography in the Old Believer culture - how this life innovation was perceived and how it came into this conservative environment, what factors stimulated the development of certain genres and how the photo was implemented in an evolving culture of the Old Believers?

2. The importance of photography as a specific type of historical and ethnographic source, its heuristic potential and possibilities of verification of such a data structure. Namely, information opportunities of the photography for comparative detection of the nature and evolution pace specific to the Old Believers in Bessarabia, Buryatia and Tuva.

\section{Discussion}

The photographs reflecting different aspects in life of the regional Old Believers are of a particular value to researchers. Firstly, a personal photography among the Old Believers has long been considered a $\sin$ and it was strictly forbidden. Therefore, the mere fact of photographing is valuable information. Available at the disposal of scientists, photos are quite rare pictures; the very existence of them provides information on the dynamics and the nature of the evolution of the Old Believer tradition in a given period. Secondly, the photos taken in this way are often a photographic reflection of different elements of national culture's treasures. The very traditional culture (in its regional variants) which was maintained and developed by the Old Believers and which in the course of economic and industrial modernization of society started quickly disappearing out of public life and turning into the "vanishing scenery".

The nature of mass photography art let us determine the following milestones in the establishment and operation periodization of photography: 1) traditional (the late $19^{\text {th }}$ century - the 30 s of the $20^{\text {th }}$ century); 2) modern (the 1940s $-1990 \mathrm{~s}$ ); 3) present (the early $21^{\text {st }}$ century). In this research we are interested in the first period of the selected ones. This is due to the fact that, firstly, within its framework there are significant changes in the Old Believer culture in different regions, and secondly, still remained Old Believers' external markers allow their definite identification in photos.

Accordingly, the turn of the $19^{\text {th }}$ and $20^{\text {th }}$ centuries represents the bottom chronological boundaries of the research, as a time of intensification in economic and cultural development of the Russian Empire, which included Bessarabia and Western Transbaikalia. The construction of Trans-Siberian railway was also crucial for the further development of the latter in this period. Natural internal milestone of the society development as a whole, and of its Old Believer component in particular, was the beginning of the First World War, the revolutionary events of 1917 and the subsequent changes in all the spheres of life. In the course of these changes, Bessarabia, Baikal and Tuva (that had been a part of the Chinese empire) occurred in fundamentally different political, economic and cultural conditions in different countries (Romania, the USSR and the Tuvan People's Republic). As the upper chronological border is the beginning of the Second World War, which led to the entry of Bessarabia and later Tuva in the Soviet Union. 
Bessarabia, Buryatia and Tuva, as the territories with strong enclaves of the Old Believers, have their own strongly marked specificity. These regions are fundamentally different from each other in a number of key parameters which enables to study a comparative research question - how much regional specificity influenced on the character of the Old Believer culture in their space? In particular, the different parameters of these regions include: geography (Bessarabia is located in the maritime areas of the South-East Europe, Western Baikal and Tuva are deep in their heartlands in the continental Asia), the climate and the possibility of economic managing (a soft Bessarabian climate and sharply continental Siberian one), demographics (high density in Bessarabia, a low one in the Trans-Baikal and even lower in Tuva), migration specificity and the history of the local Old Believers' enclaves formation (large groups of people traditionally inhabiting the area and prolonged influx of voluntary migrants - the Old Believers in Bessarabia, a relatively small number of the indigenous population and colonization in Siberia with a predominance of 'penalty' colonization in the Trans-Baikal and free colonization in Tuva), the nature and the level of economic development(involvementofBessarabia in the relatively developed European markets and agriculture, hunting and fishing economy with the availability of Siberian railway connection in the Trans-Baikal region and remoteness from the developed transport infrastructure in Tuva), cultural environment (the impact of Slavic, Turkic and other peoples' cultures of the region, as well as European technological and cultural centers in Bessarabia; the influence of different migrant groups cultures, indigenous people of the region and Buddhist-Confucian Asian countries in Siberia), etc. In addition to the above, a marked difference between the regions is the fact that, as it has already been noted, they have evolved within different political spaces. Thus, in the 1920-1930s, they were found in fundamentally different conditions of Romania, the USSR and the Tuvan People's Republic. Therefore, the Old Believers of Bessarabia and Tuva in the 1930s were not influenced by such a materialistic state modernization as the Old Believers located on the Soviet territory.

The Old Believers of Bessarabia, among other things, were characterized by the fact that they came voluntarily and developed gradually as a group of the Old Believers-Lipovans who were largely integrated into the local market, society and culture. This relative liberalism led to a significant spread of Belokrinitskaya church among them, known for its soft (by the standards of the Old Believers) doctrine with respect to the external community. This also contributed to rather late political integration of Bessarabia into the largest Eurasian state allowing to establish one of institutionalized Old Believers centers here. In particular, it is here Izmail Eparchy of Belokrinitskaya Hierarchy got a significant development, bringing together many followers of the old faith in the region, which had a large number of priests and churches and monasteries (Prigarin, 2011: 396-409).

As for the Semeiskie Old Believers of Transbaikalia, as an exiled group under the relatively strict police control in a harsh and poorly developed, from an economic point of view, region were characterized by agricultural traditionalism, they were more closed as diaspora and less involved into external relations. This was reflected in the composition of the local Old Believers' unity. There were more than thirty different parts. At the same time, immigration policy was interested in settling one direction followers in different places. This prevented them from creating big strong communities and led to the fact that in the Western Transbaikalia there was not a single village of the Semeiskie, in which all 
the Old Believers were the followers of one trend, of one religious community and went to the same church (house of worship). In some villages, there were 15 (!) different community groups. At the same time, beglopopovskoe Vietkovskoe trend consent was the most common and the mass, standing on moderately traditionalist positions. At the same time, Popovskoe Belokrinitskoe trend, known for its liberal nature, extended to economically more dense and developed western regions of the empire (in the same Bessarabia), in spite of some success of their missionary activity in the late the $19^{\text {th }}-20^{\text {th }}$ centuries, remained in absolute minority. Moreover, about 450 of its local followers were split into two groups, one which was more liberal - "okruzhniki" and, the other conservative one - "neokruzhniki", that after permissive reform of 1905-1906, refused to register their communities and make relationship with the authorities. Due to these and other reasons the Semeiskie Old Believers even after 1905 had an extremely small number of priests and did not have monasteries.

The Old Believers of Tuva were characterized by the fact that in general they voluntarily came to the region from the territory of the Russian Empire and later, the Soviet Union, due to the radicalism of their views on the state and society. This "withdrawal from the world" was based on the division of space onto the "contaminated" and "clean" and supposed not only to move into uncontrolled by the state and the Church territory, but also to preserve a clear identification of prevailing cultural stereotypes, a taboo system. Therefore, in this relatively uncontrolled territory, quite fanatic orthodox-minded Believers of different trends were concentrated. Thus, there were most of all the Old Believers of the Chapel trend. In the $19^{\text {th }}$ century, followers of the latter moved from Beglopopovtsy practice to Bespopovtsy one and became known for their relatively harsh attitude to the world and the possibility of salvation in it and out of it. Therefore, the Old Believers of the upper Yenisei and its tributaries had minimal contacts with the authorities and society, but at the same time they could develop communication among trends, a large number of secret settlements and small monasteries. The latter played the role of the powerful religious centers and influenced the life of the local Old Believers' population.

Basic photos involved in the study, were deposited in the archival, museum, research, and, most importantly, family photographic collections of Russia (Transbaikal and Tuva), Ukraine and Moldova. These photo collections were taken by authors in numerous expeditions to those territories. These are mainly pictures from the family albums of the Semeiskie and Lipovans descendants, as well as collections of museums and archives in the territory of Bessarabia, TransBaikal and Tuva. These materials were collected by the research centers of Odessa (Odessa I.I. Mechnikov National University) and Irkutsk (Irkutsk State University).

The total base of photographic material that was studied is about two thousand photographs had taken during the study period. The main genres of these photographs were: group portrait (more than a half), individual portrait, elements of church culture, rites of passage, festivals, domestic and farm scenes, etc. This separation fully reflects the degree of a genre popularity (from mass to individual). In addition, in Romania of 1920-1930 a series of photo cards devoted to some areas of Bessarabia (Izmail, Kilia, Vilkovo, etc.), which were often attended by Lipovans was issued.

Historical conditions for making this collection of photographs can be generally defined as the period of the industrial modernization in society. This process intensified in the late $19^{\text {th }}$ century within the framework of the capitalist bourgeois and state industrialization and 
continued at a qualitatively new level in the post-revolutionary period. This transition from a traditional society to the industrial one affected almost all aspects of life and inevitably entailed the forced evolution in the public culture. The modernization took place in several stages, and its natural turning-point was in 1917 with its revolutions. This period was characterized by intensifying society technification as an integral part of modernization, which was manifested in the development of new information media (photos, movies, phono, etc.). Although the same photographic technique had been invented much earlier, during this period it received a massive (not just elite) social demand for its distribution. It was a kind of transition from amateur to professional photography.

For obvious reasons, the studied photographs are divided into pre-revolutionary (taken in the late $19^{\text {th }}$ - early $20^{\text {th }}$ century) and postrevolutionary (taken in the $20 \mathrm{~s}-30 \mathrm{~s}$ of the $20^{\text {th }}$ century) ones. At the same time, it is characteristic for the pre-revolutionary photographs that they were often taken in the period from 1905 to 1917. This was due to confessional "permissive" reform, revitalization of economic development and related to it greater participation of the Old Believers of different regions in system relations in the society. This evolution removed a part of the old religious prohibitions for wealthy Old Believers and authorized them freer behavior (in particular, photography). The military service played the major role in the process of liberalization, along with trade and departure to work. That is why among the surviving prerevolutionary images of the Old Believers there is a rather large number of "military" pictures.

Pre-revolutionary photographs are usually performed by a professional artist-photographer and have a relatively high quality. Most often, the picture was taken in a photo studio of a large community (in most cases, a city), was posed and in the background there was little difference from the pictures of other citizens (not Old Believers). The background in this case was most often stands and ornamental drapery creating an atmosphere of high society elitism (columns, chairs, tables, a variety of images, etc.). Made on high quality photographic paper, a picture was stuck to the decorated embossed and stamped cardboard baguette. The name of the community and the photo shop address was often written on this baguette.

In the post-revolutionary period both in a bourgeois Romania (less) and in the Soviet Russia (more) picture quality falls. This is due to the democratization of photography, it is because of its escaping from thephoto shops and penetrating into the life of large sections of the population (including a rural one), decreasing clients' demand, photographers' professionalism and opportunities. Therefore, the exterior is often a house wall (decorated with drapery) or simply the atmosphere of photographic situation.

It is characteristic that in the studied regions, photography spread in a different way and has got a different stylistics. From all of the involved material, there are more than a thousand photos of Lipovans, the number of the Semeiskie photos is only a few hundred, and the number of the Tuvan Old Believers photos of the time is only a few dozen.

The economic and socio-cultural characteristics of Bessarabia led to wider dissemination of photographs at the turn of the $19^{\text {th }}$ and $20^{\text {th }}$ centuries. Although here, as in the other places of the Old Believers' settlement, yet, until recently, we could hear a negative reaction to the proposal to take a picture from the elderly, "Shall I show my beard to the devil?!". The fact is that the Old Believers' outlook usually shared space, objects and phenomena into the "pure" (belonging to "God") and "unclean" (belonging to "Antichrist"). An innovation that has not passed 
the test of time and practice was often perceived as "evil". In addition, the ordinariness of man and their portrait for a long time was perceived not only as a sin but as temporal matters ("metushlivoe" in Lipovan, derived from the verbs fuss or bustle). Nevertheless, the evolution of everyday life culture and worldview of Lipovans led to the appearance of not only a relatively mass group and individual portrait, but also to the photos of important life events (weddings, funerals, etc.), as well as the elements of a church culture (e.g., ritual consecration of churches, cathedrals and meetings, ordination or choristers that became almost ritual).

An important role for the development of photography among the Old Believers of Bessarabia was played by the fact that a number of the confessional center representatives were not just involved in photography, but also considered it "a service to the gods". For example, a well-known choir leader in Kilia, Ismail diocese publisher Anisim Kazakov in the 1930s, along with religious literature, distributed his homemade photos to parishes. Here is a characteristic fragment of autobiography by Antoniy Feodulovich Izotov (born in 1909): "From my childhood, I studied at the RussianRomanian school in the town of Vilkovo, where I had studied for 7 years. At the end of the civil school in 1922, I enrolled in the Peter and Paul Monastery to study Church Slavonic letters. I was taught this reading and writing by the monastery monks. In 1928, I entered to study the Old Believers' note singing, the so-called "Znamennago" to a certain Protodeacon Anisim Kazakov, in the town of Izmail at St. Nicholas Old Believers Church. In 1935, I was requested by the Old Believers Society of St. Nicholas church in Vilkovo to be a teacher of the Church Slavonic reading and singing. This is the duty I carried out for four years, from 1935 to 1938 inclusive. From 1938 until this far, I have been engaged in photography work and thanks to it I earned money to survive". In 1946, Izotov joined the fishing crew named "Dawn of Freedom" with all his equipment. When he wanted to leave it and go to the monastery, his technique as a "means of production" was not returned to the owner. Interestingly, the Bishop of Kishinev personally asked its chairman to return it, but he was refused.

Such an attitude to photography is emphasized indirectly by signatures (sometimes by half-running hand) having not so much a memorial as a "blessing" content. Photographs exchange was carried out as a gift, or a blessing from the priesthood to its congregation. A striking example: Joseph Morzhakov (in the future the locum tenens to all the ancient Christians primitives), when a bishop, wrote to the rural dean of Izmail: "I am sending you a photograph for good and prayerful memories. In view of considerable distance, we see each other very rarely, and for this I am sending you a photo that You will always look at and, if we can see people, then we are more likely to remember them, and in particular, please do not forget me in your holy prayers which we desperately needed, as in this life and in the hereafter." 2

The Semeiskie Old Believers of Transbaikalia were more conservative (Vasilieva, 2007) in this regard. Agrarian religious traditionalism had not allowed photographing and using the photos in everyday life for a long time. The first ones to use photography, like in Bessarabia, became the citizens and wealthy residents of the village, who were more involved in external economic and cultural ties. However, the nature of a local economy led to the fact that the number of such people was not great and, as a consequence, the Semeiskie Old Believers' photo in the beginning of the $20^{\text {th }}$ century is very rare. Moreover, we basically did not meet the pre-revolutionary and even pre-war photos of the Semeiskie funerals, 
weddings and other important aspects of life of the local Old Believers (wedding photos were starting to appear in the $1950 \mathrm{~s}$, and funeral ones only in the 1970s). The same fact applies to the pictures of subjects and objects of church culture, whose photography was taboo during the whole study period.

Also, if among the Lipovans the photography started taking its firm place in the home in the 1930s (placing individual portraits of relatives or cheap popular print collages with them in specific areas of living space), then among the Semeiskie such a home presentation of family photographic portraits started spreading only in the postwar period. It is obvious that some traditional components, such as icons, cheap popular prints, a mirror and towels were prerequisites for the photo in its placement in the home. Therefore the location of the photos in the honorary, socially and ritually symbolic loci system is not casual in the red (holy), where icons and other sacred things are placed, corner (in the village) and on chests of drawers (in the city).

At the same time, in the background of different rates of photo penetration into the life of the Old Believers in Bessarabia and TransBaikal, there is an example of a "negative rate" of this process. The Old Believers of Tuva (that in the early $20^{\text {th }}$ century was a part of the Chinese empire, then in the 1920-30s was developing in the framework of the Tuvan People's Republic), were found in the economically undeveloped region and had a relatively radical traditionalism, because of which they voluntarily migrated here at first from territory of the Russian Empire and then of the Soviet Union, most of them continued to maintain the ban on photographing. Moreover, the Old Believers who migrated here during the Soviet period from the regions where their fellow believers began gradually to get used to the photography, here, following the tradition, taken and codified by the decisions of the local councils of the Old Believers, photography was not allowed. Examples are some pictures of the Usinsk Old Believers, made by F.Y. Kon in 1901-1903 (Tatarintseva, Storozhenko, 2015). And if in the south of the Yenisei province, the Old Believers (presumably of Belokrinitskaya Hierarchy) could afford such liberties, then on the territory of Tuva, where they were moving in a stream of orthodox followers of the old faith, such cases are not known.

It is characteristic that if the Chapel Believers of Urals (mainly more liberal "factory" ones, in other terms, industrialists and merchants) began to allow themselves rare photographs at the beginning of the $20^{\text {th }}$ century, then their Siberian and especially Tuvan descendants and fellow believers (mostly the more traditionally minded "rural" Old Believers) did not accept photography. Therefore, we can say that the first relatively wide photographing of the local Old Believers became forensic investigative photos (especially the second half of the 1940s), and the second - photographs taken during the "archaeographic discovery of Siberia" made by N.N. Pokrovsky, his students and followers in 1965 and in the following years and decades (Pokrovsky, 2005).

Taking into consideration the variety of picture genres of the Old Believers (group and individual portraits, domestic and household scenes, religious figures and attributes of church life, holidays, rituals and so on), photographic material as a source to study such a specific theme should be divided into two main blocks. The first group contains pictures as a source on the history of folk (ethnic) culture of the Old Believers, and the second one - as a source on the history of their church (confessional) culture. Although this division is methodological in nature and rather arbitrary, this approach allows identifying the nature of the evolution of the two main dimensions of the Old Believer culture. 
At first, let us consider informative possibilities of pictures, carrying more data about the popular culture of the Old Believers.

The most common genre of photography was a portrait. As a rule, these are standardized images which were characterized by etiquette codes - static postures, straight stare, a specific, practically always the same, background. The number and quality of personal photos can reveal the nature of individualization process in the Old Believers' milieu of the study period. The most informative, in our view, are the group portraits depicting the large and small (which is also indicative) Old Believers' families. There are middle-aged Old Believers who are distinguished by their sedateness and "correctness" that, among other things, manifested their family and social power in the world of Old Believers. It is especially evident in the large family photographs. The head of the family often sits in the center, whose brothers and wife sit next to him. Sons, daughters, daughters-in-law and their children are back and sides. Everyone shows their status in a family hierarchy by their place, posture and pose to some extent. The elderly people photos are almost impossible to find, the old scrupulously observe a set of prohibitions "to communicate with the world", including in the pictures.

In most cases, the Old Believers were photographed in their traditional (often in festive) clothes. According to the picture, among other things, we can see prosperity, and the way of positioning themselves in relation to the contemporary society. The material and cut of clothing, jewelry and the manner of wearing them - all these gives an immediate idea of how the Old Believer considers himself in the society milieu. Thus, the most conservative costume remained a female one showed, as a rule, in all its magnificence. However, in the clothing material, and in the variety of ornaments, we can see the influence of fashion and the market.
Democratization of the portrait and its transition from studio into an among the people milieu have led to the fact that in such family compositions there are a lot of small details. Taking a photo, the family sought to show their status, position, and so on. Due to this, in the 19201930's, a number of "ethnographic" attributes (for example, frequent church books, toys, all kinds of folk instruments, etc.) appeared.

Analysis of the people's appearance in the photohelpstocarryoutthedetailedreconstructions. Thanks to them, we may recreate everyday and holiday costumes of the Lipovans and Semeiskie. Both of them have the most stable elements related to religious norms: obligatory belts, men beards, women's covered head, etc. At the same time, the pictures' comparison of traditional Old Believers' costumes of different regions shows their striking differences. And if the appearance of men differs to a lesser extent (e.g. - short hair, little use of embroidery on a shirt-blouse, width and pattern of woven belts, winter clothing elements of Siberians among the Semeiskie), then the appearance of women differed greatly. Fabric, style and sarafan (sundress) decoration, clasp (of an apron) and shirts with undershirts, there was also difference in kichka "old woman's headdress" (with a pearl or bead fringe among the Semeiskie and sbornik "married woman's headdress" among the Lipovans) and covered with a shawl (or a headscarf), ornament and sizes of woven belts, outerwear (kurmushka "slim line women's outerwear with gathers at the back" and a housecoat among the Semeiskie, or sundress set "furcoat", or the two-part "the upper part + skirt" among the Lipovans), shoes and jewelry (cufflinks on a shirt, an amber or glass necklace in both groups).

Also, despite the fact that housing and other buildings got into the shot very rarely (often fragmentarily), available snapshots allow ethnographers to compare different elements 
of the Old Believer traditional architecture in different regions. It relates to the specifics of the homestead and house, decoration of windows, gates, steps, fences and others. The same applies to household items, household equipment, transport and others.

In the 1920-1930s, both in Romanian Bessarabia and Soviet Trans-Baikalia amateur cameras, democratization of photography and photographic technology simplification were propagated. This leads not only to the spread of photographing as a subject of culture, but also to mass fixation of growing evolution in the Old Believer communities. Although this evolution, for various reasons, has taken place in a bourgeois Romania, and in the Soviet Russia, changes in everyday life and behavior of the Soviet Believers were more visible. If in a relatively steadily developing Romanian society, the rate of evolution of the Old Believer folk culture was determined by the growth of their wealth, then in the Soviet territory the determining factor was a forced all-round modernization.

In both countries, group portrait remains a majorgenre of photo. But, ifbefore it, almostalways there was a picture of relatives (sometimes few generations of the same family), later (due to the evolution of patriarchal foundations), we can find more and more young people in a group portrait of the Semeiskie - "friends" and so on. Although, there are photos where all the people are dressed in traditional clothing, we can often see a part of them dressed à la "Semeiskie" (mostly women), and others - in the "new" (modern) style (mostly men). Even in a family photo of the 30s, along with the representatives of the older generation dressed in the traditional clothing and girls, we can see boys and young men dressed in "the new fashion". In other words, the modernization process affected pedagogy directly and tried to socialize the younger generation in "the new" way, not in "the old" one, not in "a family-like" one, not in "the Old Believer-like" one. So, now, in the photographs taken in the Soviet territory, the younger generation, whose appearance and behavior reveal the changes taking place in the society are increasingly represented.

It is characteristic that in the context of women's "orthodoxy", the Semeiskie men look a little freer in clothes and demeanor. And although most of the remaining photos represent us men in traditional dress, there are a number of pictures in which young Semeilskie men of the 30s afforded some liberties (a cap and even a shirt with a turnover collar and a cut in the middle). And such a refusal from the traditional shirts is incredible, especially when some of the young Old Believers are shaven (!) and sit with their legs crossed. These changes in the behavior stereotypes of the representatives of the Semeiskie Old Believers' youth are quite revealing. They displayed the inevitable evolution of exterior in the life among the liberally minded youth. At the same time, a big role in this "not Old Believer" socialization of young men in the imperial, and even more so, in the Soviet period, was played by the military service. Indeed, in most "military" photos there are not only inevitable in this situation, but also voluntary divergences with the Old Believer tradition. This tendency is convergent to the Lipovanskie milieu. It is the "youth photo" of the 1930s that demonstrates the secularization of life.

At the same time, official photography genre receives a significant development effort in the Soviet society: pictures of party cells, teams, staff of organizations, shock workers, delegates, etc. Along with a posed portraiture, pictorial photography gets its development: elections, celebrations, etc. There are also people looking like the typical Semeiskie ones (there are a majority of them in the pictures) who often got into the same shot with the activists dressed in a "new" way. Also, among the staff, we can 
see a young woman-activist who wears a dress instead of a sundress. Among other things, this may indicate that not all the Old Believers were eager to part with their tradition, even in terms of cooperation with the authorities, and interactions with other community groups. However, if earlier the Semeiskie believed that "it was forbidden either to pray to God, or to sit at the table with strangers", now pictures with a mixed team of staff are not uncommon (Kostrov, 2010: 375). This means that the strengthening and development of various kinds of contacts with the representatives of other groups in a new social construction.

Both in the pre-revolutionary and postrevolutionary time, nature and measure of development and dissemination of photography among the Lipovans and Semeiskie were different. Both groups have similar shots with the elements of traditional folk and new secular culture, which, among other things, serve as indicators of socio-economic prosperity (a gramophone, an accordion, a samovar, etc.), relation to the existing elements of church culture develops quite differently.

Then, among the Lipovans photographs with the deliberate (sometimes in the center of the composition) availability of faith attributes (books, icons, church clothes, etc.) became popular. Moreover, at this time some the Lipovans as the representatives of the religious centers and community - priests, deacons, theologians are equipped with cameras. For example, a rich body of photographs from different Danube communities left behind father Anisim Kazakov the archdeacon of Kiliya. Similarly, the sexton of Muravlevka, Mark Mikheevich Silakov filmed not only memorial events, but everyday reality of the village. Thanks to these people that progress was achieved in the life of the local Old Believers.

Like many innovations in the Old Believers' milieu, the use of light and shade passed its testing stage. Religious consciousness continued to play an important role in it. A striking example is the spread of almost iconographic photoimages of Metropolitans, church hierarchs and some priests among the Lipovans of Bessarabia. They took their place in temples and home icon locations well before appearing of the wide photo shooting in a daily life of the local Old Believers. Approaching on the value to the holy images, the image of "their" arch-pastors decorated a sacred space in churches and homes. In the 1930s, there appear not only the images of living priests of a parish or diocese, but also man-made collages with retrospectives (e.g., a general view of all Belokrinitskii Metropolitans - from Ambrose to Innokenty). After them there appeared cheap popular images of various shrines of the Old Believers (photoimages of icons or temples). Also, photo reports of important events in the life of communities (e.g., photo shooting of moments of worship or parishioners assemblies led by the clergy) appeared at that period.

The most expressive group of pictures may be the portraits of church hierarchs, coenobites and priests. Overall, photo portraits of Metropolitans, locum tenens, and the majority of the bishops were identified in the Lipovans milieu. The first photos of the priests appeared it the beginning of the $20^{\text {th }}$ century, but their number significantly increased in the 1920s - 1930s. There are also coenobites and novices of all diocesan monasteries - photo memory keeps not only father superiors, but also monks, and some obedients. But there are fewer deacons whose photos were made less than their teachers' ones. Most often, they are photographed next to their students learning to read and sing church songs.

There are photo reports related to this group from diocesan meetings, congresses or priesthood ordination of a spiritual parent. A considerable number of these images emphasize the importance of these events for the Old Believers' milieu. The events of 1935, when Phenogen was replaced by 
the church hierarch Siluyan, can be considered as especially popular. In these photographs there were not only the motive of documenting the events but also of propaganda of the god-fearing church hierarch and his legitimacy.

We especially emphasize a set of photos by the known Old Believers' personality Fyodor Yefimovich Melnikov. Domestic and event photos of this outstanding dogmatists and literate, undoubtedly reflect his fate and preferences. For example, almost all his pictures there is a certain book or notebook as a sign of his book-learning and erudition.

Despite the fact that there are some early photos of the Lipovans wedding (in 1896) or funerals (in 1915), they started to be taken in large quantities only since 1920s. All the examples of such photos represent an urban environment, or belonging to the wealthy strata of the agrarian society (priests, teachers, innkeepers, and so on). Most often, the images of these events are standardized, there is a linear standing position of the ceremony participants in static poses. Their mass scale allows us to speak about the stability both of individual elements and ritual subjects and transformations. For example, the binding attributes of wedding processions were icons, blessings of parents that held, together with the priest, a central place in a composition a married couple only marked the geometrical axis of the image. However, judging by the photos, in the 1930s, the traditional kichka was replaced by a modern style bridal veil. The custom of taking pictures of funerals obviously came to the Lipovans from their neighbors (especially, from Moldovans, Bulgarians and Gagauz whose photos on the subject are an essential part of their family photo albums). Sacralization of remembrance of the deceased rapidly spreads thanks to photography and photo distribution to those who could not attend the funeral service.
We should recognize uniqueness of photos of other rites. Many of calendar holidays stimulated photography (according to the records on the photo back, many of the images are made after services at the respected church dates of Easter, Pentecost, Christmas and so on). However, people were not allowed to shoot their internal practices - praying required concentration, not worldliness. Therefore, a few examples of religious processions and other elements of religious manifestations are especially valuable. For example, special attention should be paid to Epiphany and blessing of water in Lake Kitai near Muravlevka or Singing of short religious ceremonial anthem (Prestol'noe velichanie) of Great Martyr Paraskeva in Karyachka (Mirnoe). It may be noted that later on, the moments of church service were rarely the subject of photo reports.

At this time, the Semeiskie Old Believers do not take pictures of Church subjects and objects. This is due to two main reasons. First, the orthodox sets, including a ban on photographing the sacred, were preserved despite the Soviet modernization of culture and life. Although at the disposal of researchers there are several photos of Old Believer leaders, operating in the territory of Trans-Baikal (bishop Athanasius, father A. Puchkov, et al.), these are, as a rule, the pictures of liberal Belokrinitskiy hierarches, not typical Old Believers' milieu. Also, the exception, that proves the rule most likely, is a single photo of Belokrinitskiy religious procession in May 17, 1909, which, according to archival materials, has caused surprise and confusion among most of the local Old Believers. However, the senior choir singers of other, more or less massive groups, were violently set against to be photographed and did not allow taking pictures of the different sides of the church culture. There are no even photos of the Semeiskie in prayer costumes. The absence of such photographs indicates the degree 
of strict access preservation to the sacred among the "Semeiskie" of Transbaikalia in the first third of the $20^{\text {th }}$ century. Available set of photographs clearly shows how and to what extent the local Old Believer world went on contact with the surrounding society and state both before the revolution and after it. Second, the Soviet antireligious policy led to the fact that the Old Believer church culture that in pre-revolutionary times up until 1905 was practiced secretly, in the new conditions it was forced to go underground more than before and not to show their subjects (senior choir singers and priests ) and objects (books, icons, prayer houses).

But even such number and quality of images is a rate of relatively successful penetration of photography into the culture of the Old Believers. While the Old Believers of Tuva in the analyzed period continued to deny photographing and appeared in photographs mostly as suspects or in an unexpected situation for themselves (for example, a group photo of a mixed company). In the mixed company, only "worldly" (communicating with the outside world) Believers can be photographed. While the "synodical" (who limited external contacts) could be forced to be photographed only on forensic and investigative photographs.

We can conclude that during the first third of the $20^{\text {th }}$ century for objective reasons the Old Believers of Western Transbaikalia showed a greater level of traditionalism than the Old Believers of Bessarabia, which, inter alia, manifested a relatively low penetration rate of photography into their culture. But even their experience from the standpoint of taboo conservation was relative, compared to the behavior attitudes and stereotypes of the Believers in Tuva.

\section{Conclusion}

In the process of entering into the life of the Old Believers in different regions, photography reflected the fact of a large number of specific differences that characterizes, in particular, folk (ethnic) culture of the Lipovans and Semeiskie in Bessarabia and Trans-Baikal. At the same time, the photo reality reflected the differences in evolution and, as a consequence, their attitude to photographing a church culture in different regions where the Old Believers lived. And if the Lipovans began taking pictures of various components of church culture more and more, the Semeiskie did not. This was due to both the level of their traditionalism, and a clandestine state in which the "old faith" was in the 1930s in the Soviet territory. So, if among the Lipovans photography is a relatively massive source for research of both popular culture and the church one, then among the Semeiskie it is much more modestly represented as a source for the popular culture study. For the Old Believers, who settled in Tuva at the headwaters of the Yenisei River and its tributaries, due to remoteness from the economic centers and communications, and most importantly - due to heightened traditionalism of the voluntary refugees who fled to this remote place, photography remained strictly prohibited. However, it does not mean that it is not the source of their history. The fact of maintaining this ban and availability of rare photos of the worldly Old Believers, who violated this ban, say about the degree of conservation and development of the traditionally oriented Old Believer culture in the Upper Yenisei.

Photography, as well as many other cultural elements, in the Old Believers' milieu has undergone the stage that corresponds to the "old". Having found the prototypes in a previous practice (icons, books as a communication area, towels, mirrors and so on), the Old Believers from different regions over time, gradually began to accept this technological innovation. But, for a long time, its existence was realized like something alien. The nature and the measure of 
this attitude were determined by both objective and subjective conditions of the milieu of the Old Believer community.

Based on a retrospective, functional and comparative historical analysis, we can reveal the properties of photography as an object of the Old Believer practice in the first third of the $20^{\text {th }}$ century. In this respect, we still have to work on the reconstruction of its predecessors' code to enter the photograph into the overall process of cultural development (for example, the connection with icons, popular prints, folk texts, etc...). In addition, in the future, we can follow the evolution of the attitude to it and its existence forms in the milieu of the Old Believers in different regions in the ensuing years. For example, the use of photographs in some rituals (the custom to put pictures on the gravestone monuments with / instead of the Christian formula-remembrance on the cross) and other cultural complexes. However, at this stage, we can conclude that photography is a valuable source for retrospective study of both the evolution of the Old Believer culture from different regions, and for identifying its comparative specific features.

\section{References}

Alexandrov, E.V. (2005). Spectr problem vizualnoi antropologii [Spectrum of the Visual Anthropology Issues], In VI kongress etnografov $i$ antropologov Rossii [The $6^{\text {th }}$ Congress of Ethnographers and Anthropologists of Russia]. Spb, MAE RAN, 380-383.

Barthes, R. (1997). "Camera Lucida”. Fragmenty ["Camera Luchida”. Fragments]. Moscow, Ad marginem, $155 \mathrm{p}$.

Buraeva, S.V. (2005). Materialy Arkhiva UFSB po respublike Buriatia kak istochnik po istorii staroobriatcheskoi knizhnosti Zabaikalia [Materials of the UFSB Archive for the Republic of Buryatia as the Source of the Old Believers Book Learning of Transbaikalia], In Konfessii narodov Sibiri v XVII-XX vv.: razvitie i vzaimodeistvie [Confessions of the Siberian Peoples in the 17th $-20^{\text {th }}$ Centuries: Development and Interaction]. Irkutsk, Ottisk, 225-229.

Vasilieva, S.V. (2007). Fotodokumental'noe istochnikovedenie po istorii semeiskikh Zabaikalia [Photodocumentary Source of the History of the Semeiskie of Transbaikalia], In Staroobriadchestvo: istoria i sovremennost, mestnye traditsii, russkie i zarubezhnye sviazi [Old Believery: History and Contemporaneity, Local Traditions, Russian and Foreign Connections]. Ulan-Ude, BGU, 159-161.

Karpenko, S.V. (2013). Istina mozhet byt' ustanovlena tol'ko na osnovanii dokumentov. Arkhiv generala P.N. Vrangelia i izuchenie istorii belogo dvizenia na iuge Rossii [Verity Can Be Established Only on the Basis of Documents. Archive of General P.N. Vrangel and Studying of the White Movement History in the South of Russia], In Vestnik arhivista [Archivist herald], 2 (122), 274-286.

Kovrigina, I.A., Kostrov, A.V. (2012). P.N. Vrangel v Irkutske (1902-1906): "documentalnie zhizneopisania" i arkhivnie dokumenty [P.N. Vrangel in Irkutsk (1902-1906): "Documentary Biography" and Archival Documents], In Novyi Istoricheskii Vestnik [New Historical Herald], 32, 57-65.

Kostrov, A.V. (2015). Obrazy vneshnego i vnutrennego vragov sovetskogo gosudarstva v predvoennom filme Alexandra Dovzhenko "Aerograd" [Images of External and Interior Enemies of the Soviet State in the Pre-war Film of Alexander Dovzhenko "Aerograd"], In Novyi Istoricheskii Vestnik [New Historical Herald], 43, 60-67.

Kostrov, A.V. (2010). Fotomaterialy kak istochnik po istorii semeiskikh staroobriadtsev Zabaikalia v pervoi treti XX veka [Photographs as a Source on the History of the Semeiskie Old Believers of 
Transbaikalia in the First Third of the 20 Century], In Vestnik Tambovskogo universiteta [Tambov University Herald], 3 (83), 327-333.

Lishaev, S.A. (2007). Staraia fotografia (veshch', obraz, raspolozhenie) [Old Photograph (Item, Image, Location)], In "Mixtura verborum"-2007: sila prostyh veshchei ["Mixtura Verborum"-2007: the Power of Simple Things], Samara, SGA, 3-10.

Males, L.V. (2007). Fotografia v sotsiologicheskih distsiplinah [Photo in Sociological Disciplines], In Visual'naia antropologia: novye vzgliady na sotsial'nuiu realnost' [Visual Anthropology: New Views on Social Reality], Saratov, Nauchnaia kniga, 168-182.

Nurkova, V.V. (2006). Zerkalo s pamiat'iu. Fenomen fotografii. Kulturno-istoricheskii analiz [Mirror with the Memory. Phenomenon of the Photograph. Cultural-Historical Analysis]. Moscow, RGGU, 126 p.

Petrovskaia, E. (2002). Neproiavlennoe. Ocherki po filosofii fotografii [Unmanifested. Essays on the Philosophy of Photography]. Moscow, Ad Margenium, 205 p.

Pokrovsky, N.N. (2005). Puteshestvie za redkimi knigami [Tourney for the Rare Books]. Novosibirsk, ID Sova, 344 p.

Prigarin, A.A. (2011). Fotografii kak istochnik dlia izuchenia staroobriatchestva Izmail'skoi eparhii [Photographs as a Source for the Study of the Old Believers of Izmail Eparchy], In Staroobriatchestvo: istoria, kul'tura, sovremennost' [Old Believers: History, Culture, Modernity], Moscow-Borovsk, 2, 396-409.

Tatarintseva, M.P. (2006). Staroobriatsy v Tuve: Istoriko-etnograficheskii ocherk [Old Believers in Tuva: Historical and Ethnographic Essay]. Novosibirsk, Nauka, 216 p.

Tatarintseva, M.P., Storozhenko, A.A. (2015). Staroobriatsy v Tuve: retrospektiva i sovremennost [Old Believers in Tuva: Past and Present]. Saarbrucken: Lambet Academic Publishing, 137 p.

Tolmachova, E.B. (2009). Poniatie etnograficheskoi fotografii [Definition of the Ethnographic Ehotograph], In VIII Kongress etnografov $i$ antropologov Rossii [the $8^{\text {th }}$ Congress of Ethnographers and Anthropologists of Russia]. Orenburg, OGAU, 581-584.

\section{Abbreviations}

РПСЦ (RPSTS) - Русская Православная Старообрядческая Церковь [Russian Orthodox Old Believers Church];

СССР - Союз Советских Социалистических Республик [United Soviet Socialistic Republic];

ТНР — Тувинская Народная Республика [Tuvian People’s Republic]. 


\title{
Фотография как источник
}

\section{для компаративного исследования}

истории и культуры

локальных групп старообрядцев

в первой трети XX столетия

(на примере старообрядцев Бессарабии,

Бурятии и Тувы)

\author{
А.В. Костров ${ }^{\text {a }}$ А.А. Пригарин ${ }^{6}$ \\ ${ }^{a}$ Иркутский государственный университет \\ Россия, 664003, Иркутск, ул. К. Маркса, 1 \\ ${ }^{6}$ Одесский нацииональный университет \\ им. И. И. Мечникова \\ Украина, 65000, Одесса, ул. Дворянская, 2
}

\begin{abstract}
Важным источником для исследования истории и культуры локальных групп старообрядиев в первой трети XХ в. являются фотоматериалы. Сам факт фотографирования, жанры фотографий, внешний вид запечатлённых и окружающий их предметный мир носителей культуры - всё это даёт массу ценного материала для изучения регионального староверия в означенный период. Анализ изменения количества, качества и содержания фотоматериалов того времени позволяет оченить характер и темпы эволючии старообрядческой культуры. Также фотодокументальное наследие, отразивщее особенности старообрядческой культуры разных регионов, в рамках компаративного подхода позволяет выявить и подвергнуть всестороннему анализу специифику локальных старообрядческих сообществ.

В статье поэтапно исследуются вопросы теории и практики источниковедческого использования фотографии, выявляется общее и разное в исторических условиях развития старообрядческих сообществ Бессарабии, Бурятии и Тувы. Предпринимается компаративное соотнесение комплексов фотографий, отразивших их жизнь в исследуемьй период. Делается вывод, что фотоматериалы позволяют существенно расширить и уточнить данные других типов источников, а также дают возможность выявить специфику характера и эволюиии традииионной культуры старообрядиев разных регионов в народном и церковном её измерениях.
\end{abstract}

Ключевые слова: старообрядчество, старообрядиы, семейские, липоване, фотография, исторический источник, Бессарабия, Бурятия, Тува.

Эта статья была подготовлена при поддержке гранта Гуманитарного научного фонда Российской Федерации № 16-14-17601.

Научная специальность: 07.00.02 - отечественная история. 